\title{
Cell surface antibodies in Type 1 (insulin-dependent) diabetic patients
}

\author{
I. Presence of immunoglobulins $M$ which bind to rat pituitary cells \\ M. Vercammen, F.Gorus, A. Foriers, O. Segers, G. Somers, M. Van de Winkel and D. Pipeleers \\ Department of Metabolism and Endocrinology, Vrije Universiteit Brussel, Brussels, Belgium
}

\begin{abstract}
Summary. A standardized method has been developed for the assay of cell surface antibodies in IgM- and IgG-fractions from human serum. Suspensions of adult rat islet B cells, islet non-B cells, and anterior pituitary cells were used as antigen source and a cell sorter as analyser of the immunoglobulin binding to individual cells. Assay conditions were selected wherein no surface antibodies were detected in 33 control subjects younger than 20 years. In $30 \%$ of Type 1 (insulin-dependent) diabetic patients, surface antibodies were measured with rat anterior pituitary cells as well as with rat islet B cells. Binding to pituitary cells occurred with IgM- and IgG-fractions and correlated positively with $\operatorname{IgG}$ binding to islet $B$ cells. At onset of the disease, the prevalence of IgM-rat anterior pituitary cell surface antibodies was higher than that of IgG-rat anterior pituitary cell surface antibodies. Cell surface
\end{abstract}

antibodies were also detected in first-degree relatives of Type 1 diabetic patients, but corresponded primarily to IgMrat anterior pituitary cell surface antibodies. It is concluded that the development of Type 1 diabetes in subjects younger than 20 years is associated with the generation of both IgM and IgG cell surface antibodies. The IgM surface antibodies may result from stimulated production of polyreactive natural autoantibodies and could precede the switch to the formation of monoreactive IgG autoantibodies. The assay of IgM cell surface antibodies can be useful in studies on the sequence of immune events in diabetes and other autoimmune disease.

Key words: Pituitary cell surface antibodies, islet B cell surface antibodies, Type 1 (insulin-dependent) diabetes mellitus.
The development of Type 1 (insulin-dependent) diabetes mellitus is associated with the appearance of antibodies against pancreatic B cells [1-6]. At clinical onset of the disease, more than $70 \%$ of patients present circulating immunoglobulins $\mathrm{G}$ ( $\operatorname{IgG}$ ) which bind to surface and/or cytoplasmic antigens of normal islet B cells $[3,4,7]$. These immunoglobulins can also occur in the preclinical stage [8-10], whereas their prevalence decreases after clinical onset $[11,12]$. They have been proposed as markers for the destructive process in the endocrine pancreas $[8,9]$. It remains, however, unclear whether the islet $\mathrm{IgG}$-antibodies are generated before, during or as a consequence of the killing of islet B cells. It is also unknown whether their production is preceded by the formation of immunoglobulin M (IgM)-autoantibodies as in classic immune responses. If the purpose is to identify early stages in the development of diabetes and to understand the sequence of immune alterations in this disease, it may be useful to examine whether IgM-auto-antibodies are formed in these patients. In this perspective we have developed a stan- dardized cell surface antibody assay for the quantification of IgM and IgG-binding to living cells. Since Type 1 diabetic patients are known to develop IgGautoantibodies against cytoplasmic antigens of different endocrine cell types [1,13-15], we have measured in this assay the IgM and IgG-binding to islet $B$ cells as well as to other endocrine islet cells and to pituitary cells.

\section{Subjects, materials and methods}

\section{Patients}

Sera were collected from Type 1 diabetic patients under the age of 20 years. All presented a ketosis-prone state of hyperglycaemia and required insulin treatment. The onset group comprised 30 individuals, with a mean age of 14 (range 3-20) and a male/female ratio of $15 / 15$. A second group consisted of 27 patients treated with insulin for less than 3 years and presenting an age distribution of 3 to 20 years (mean $13 ; 16$ males, 11 females). The third group was treated with insulin for more than 3 years, consisted of 31 patients - 12 males $/ 19$ females - in the age range of 10 to 20 years (mean 16). 


\section{Control subject}

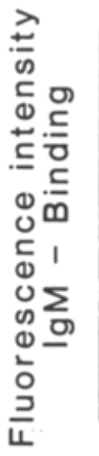

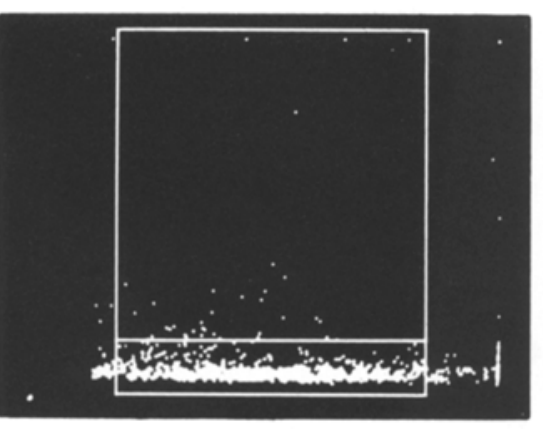

Type 1 diabetic patient

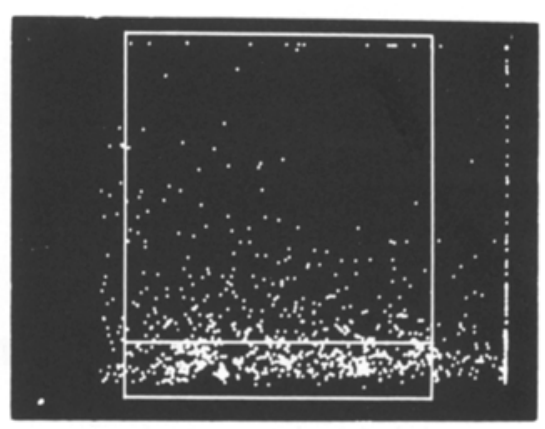

Fig. 1. FACS-analysis of IgM-binding to rat pituitary cells. Cells were incubated with 100 -fold diluted IgM fractions. Cell-bound immunoglobulins were labelled with thodamine-conjugated anti-human immunoglobulins. Each cell is plotted according to its forward scatter intensity and rhodamine-associated fluorescence intensity. The left panel represents a dot plot for an IgMfraction from a non-diabetic control subject. It is similar to that of the negative control subjects. More than $90 \%$ of the particles are recovered at low fluorescence intensity. The right panel represents a dot plot for an IgM-fraction from a Type 1 (insulin-dependent) diabetic patient. It is similar to that of the positive control subjects. More than $10 \%$ of the particles are recovered in the window of higher fluorescence intensity

\section{Forward scatter intensity}

\section{Control subjects}

The control group consisted of non-diabetic children and adolescents who were hospitalized - during the period of study - in the department of surgery. None presented clinical or biological signs of acute infection nor familial antecedents of diabetes mellitus or other autoimmune disease. The group comprised 33 individuals under 20 years (range 3-14 years - mean 8; 23 males, 10 females).

Sera were also collected from 18 non-diabetic first-degree relatives of Type 1 diabetic patients, all relatives being younger than 20 years. This group consisted of 6 brothers, 10 sisters and 2 children from Type 1 diabetic patients that had been diagnosed before the age of 20 years. The mean age of the group was 14 years (range $5-20$ years) and the male/female ratio $6 / 12$.

\section{Preparation of samples}

Venous blood $(5 \mathrm{ml})$ was collected in plastic tubes, coagulated at room temperature and centrifuged within $1 \mathrm{~h}$ at $1000 \mathrm{~g}$ for $15 \mathrm{~min}$. Serum was stored at $-20^{\circ} \mathrm{C}$. On the day of analysis, sera were thawed, mixed and filtered through a $0.22 \mu \mathrm{m}$ Millex-GV membrane (Millipore, Brussels, Belgium) before fractionation by HPLC gel filtration. The HPLC apparatus (LKB, Bromma, Sweden) was equipped with an HPLC controller (model 2102), an HPLC pump (model 2150), a UV detector (Uvicord SD - model 2158), a 2 channel recorder (model 2210) and a sample collector (Ultropac II model 2070). The Ultropac column (Toya Soda Company Gel 3000 SW) was protected by a precolumn (TSK-SWP Ultropac, LKB). Samples of $200 \mu 1$ filtered serum were injected and column fractions eluted with phosphate buffered saline (PBS) (pH 7.4) supplemented with $7.5 \mathrm{mmol} / 1$ azide. The elution positions of IgM and IgG were determined by class-specific immunoglobulin assays using low concentration radial immuno-diffusion plates (LC-Partigen - IgG or IgM, Behringwerke AG, Marburg, FRG). The fractions corresponding to the IgG or IgM peaks were pooled and supplemented with bovine serum albumin (BSA) to a $1 \%$ final concentration. Gel filtration resulted in 10-fold dilution of the two Ig-classes and in their recovery at $80 \%$.

\section{Cell isolation}

Purified islet $B$ and non-B cells were obtained according to previously described procedures [16-18]. Briefly, islets of Langerhans were isolated from collagenase digested pancreata of adult male Wistar rats and dissociated by trypsinization into single cells (crude collagenase, crystalline trypsin, bovine pancreatic DNase, Boehringer, Mannheim, FRG). The islet cell suspension was subjected to autofluorescence-activated cell sorting for the separation of B cells ( $>95 \%$ pure) from other endocrine islet cells (islet non-B). More than $95 \%$ of the isolated islet cells were positive in the neutral red vital staining.

Anterior pituitary cells were also isolated from adult male Wistar rats. Single cells were obtained by treatment of the pituitaries with trypsin and DNase and dispersion in a calcium-free medium; the method was similar to that of Denef et al. [19], except for the use of lower trypsin concentrations $(500 \mu \mathrm{g} / \mathrm{ml})$. Cell suspensions were filtered through a Percoll layer with a density of $1.085 \mathrm{~g} / \mathrm{ml}$ (Pharmacia, Uppsala, Sweden) in order to remove erythrocytes. The fraction collected at the interphase was composed of 40 to $50 \%$ growth-hormone containing cells, 30 to $40 \%$ prolactin-cells, and less than $10 \%$ of each of the other cell types [20]. More than $95 \%$ of cells accumulated the vital dye neutral red.

\section{Cell surface antibody assay}

The isolated cells ( 5 to $8 \times 10^{4}$ cells in $200 \mu$ ) were incubated with IgG- or IgM-column fractions for $60 \mathrm{~min}$. Islet $\mathrm{B}$ cells and pituitary cells were kept at $4^{\circ} \mathrm{C}$ and islet non-B cells at $37^{\circ} \mathrm{C}$, the conditions under which cell reaggregation remained minimal. At the end of incubation, the cells were washed twice $(7 \mathrm{~min}$ at $300 \times \mathrm{g})$ in Earle'sHepes medium [18] wherein $7.5 \mathrm{mmol} / \mathrm{I} \mathrm{NaCl}$ was replaced by an equimolar concentration of sodium azide. They were then resuspended in $140 \mu \mathrm{l}$ of this medium containing rhodamine labelled swine anti-human-immunoglobulin antiserum (1:40, Nordic, Tilburg, The Netherlands), incubated again for $30 \mathrm{~min}$, washed and finally fixed in $4 \%$ (volume/volume) formaldehyde. The cell preparations were analysed by fluorescence microscopy (Leitz dialux $20 \mathrm{~EB}$, Wetzlar, FRG) and by fluorescence-activated cell sorting (FACS) analysis.

Fluorescence microscopy was used to visually assess the occurrence of membrane bound fluorescence, to determine appropriate working dilutions at which virtually no cells bound with Ig-fractions from non-diabetic control subjects and to select negative and positive control samples (i.e. samples yielding respectively less than $5 \%$ and more than $25 \%$ cells with surface labelling). Binding with undiluted column fractions (i.e. a 10-fold final dilution as compared to serum) resulted for some control IgM-fractions, in highly variable percentages [5-25] of positive pituitary cells. This was no longer the case at 10fold diluted IgM-column fractions (i.e. a final 100-fold dilution), so that all binding studies with $\operatorname{IgM}$ were carried out at the higher dilution.

A Becton-Dickinson FACS IV or Facstar (Sunnyvale, Calif. USA) equipped with a 2025-05 or 2016-04 Argonlaser (Spectra Physics, Mountain View, Calif. USA) was used to quantify the percentage of fluorescent cells. Excitation wavelength was set at $514,5 \mathrm{~nm}$. Emission was selected with an LP $580 \mathrm{~nm}$ interference filter (Scott, Mainz, FRG). The negative control samples that were selected by fluorescence microscopy, produced a homogeneous distribution of the cells during cell sorter analysis, thus delineating the window of non-fluorescent cells; the area with the same light scatter activity but higher 


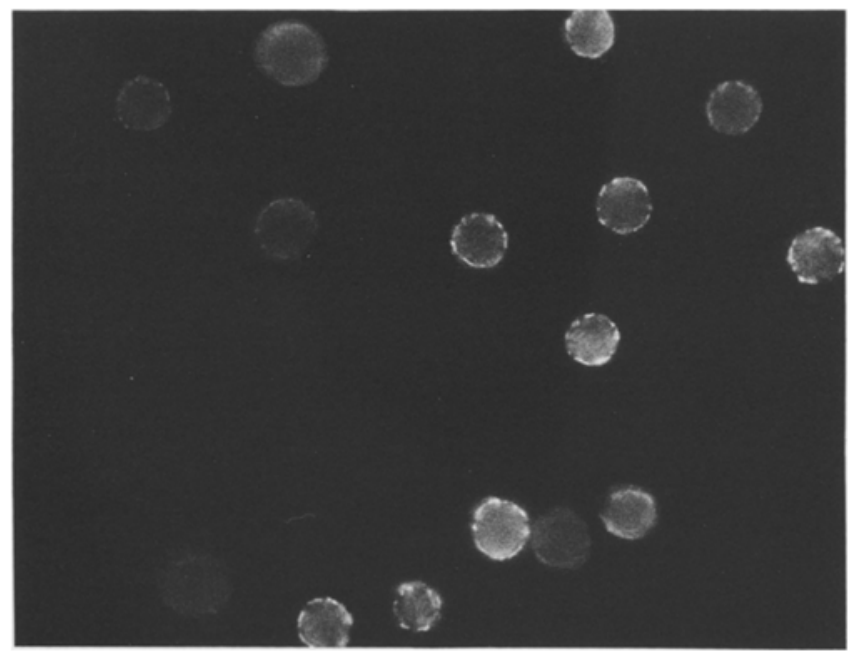

Fig. 2. Fluorescence-micrograph of anterior pituitary cells after binding with IgM-fraction from a Type 1 (insulin-dependent) diabetic patient $(730 \mathrm{x})$. The cells have been sorted from the high fluorescent window (see Fig.1 - right panel). Virtually all cells exhibit a membrane fluorescence, but the fluorescent intensity varies from cell to cell

fluorescence intensity was taken as the window of fluorescent cells (Fig.1). Analysis of negative control samples consistently recorded less than $10 \%$ of the examined particles in the window of fluorescent cells. When isolated, most of these fluorescent particles were found to correspond to extracellular material and to dead cells, presenting a uniform cytoplasmic fluorescence. In each assay, one blank (B - i.e. cells incubated without human immunoglobulins), one positive and minimally three negative control samples were included and analysed in order to set the windows for the fluorescent and non-fluorescent cell populations and to determine the mean percentage of fluorescent particles for negative control sera (C). For each unknown sample X, the percentage of fluorescent cells was measured by cell sorter analysis and used to calculate its positivity ratio as

$\%$ positive particles in $\mathrm{X}-\%$ positive particles in $\mathrm{B}$

$\%$ positive particles in $\mathrm{C}-\%$ positive particles in $\mathrm{B}$

This ratio accounts for interassay variability in the negative control subjects and will, for this group, by definition approximate 1 . The ratio for the non-diabetic control subjects is also expected to be close to 1 as a result of the selected assay conditions. The intra- and inter assay coefficients of variation on the FACS ratio's were respectively 13 and $17 \%$

\section{Adsorption of surface antibodies}

Samples containing surface antibodies against anterior pituitary or islet cells were re-analysed for the presence of rat anterior pituitary cell (APSA) or rat islet B cell surface antibodies (ICSA) after they had been exposed for $60 \mathrm{~min}$ to anterior pituitary cells $\left(4.10^{5} / 600 \mu \mathrm{l}\right)$, to islet cells $\left(4.10^{5} / 600 \mu \mathrm{l}\right)$ or to splenocytes $\left(10^{6} / 600 \mu \mathrm{l}\right)$ isolated from adult Wistar rats. A higher number of splenocytes was used to compensate for their smaller cell surface.

\section{Protein glycosylation}

Glycosylated haemoglobin ( $\mathrm{HbA}_{1 \mathrm{c}}$ ) was determined by isoelectric focusing [21]. Serum proteins were also glycosylated in vitro by incubating the sera for $20 \mathrm{~h}$ at $500 \mathrm{mmol} / 1$ glucose at $37^{\circ} \mathrm{C}$; under these conditions, serum fructosamine levels increased twofold [22].

\section{Statistical analysis}

An unknown sample was considered as positive if its positivity ratio exceeded the mean positivity ratio in the normal control group by 3 SD. Each patient group was compared with the normal control group by assessing whether the difference in the respective mean positivity ratio's was statistically significant using a one-tailed $t$-test. The prevalence of different types of autoantibodies was compared with a chi-square test using Yates-correction.

\section{Results}

\section{Detection of anterior pituitary cell surface antibodies (APSA)}

Incubation of anterior pituitary cells with IgM- or IgG serum fractions from Type 1 diabetic patients (final dilution 1:100) resulted, in a number of cases, in fluorescent labelling of the cell surface. When the suspensions with fluorescent cells were analysed in the cell sorter, 10 to $40 \%$ of the particles fell in the window of high fluorescence intensity (Fig. 1). Sorting of these particles yielded a preparation which consisted mainly of cells with a distinct membrane fluorescence (Fig. 2). Most cells recovered in the low-fluorescence window lacked any membrane fluorescence.

Incubation of IgM-fractions from diabetic sera (final dilution 1:100) with anterior pituitary cells produced a higher mean FACS positivity ratio than that measured for control sera (0.99-SD 0.21). The ratio was significantly $(P<0.01)$ increased for both recent-onset patients (1.35-SD 0.79) and patients with less than 3 years insulin treatment (1.52 - SD 0.93) (Fig. 3), but no more for patients with longer treatment $(1.07$ SD 0.50). Parallel binding experiments with IgG fractions (final dilution 1:100) produced mean FACS positivity ratio's which did not differ significantly from that in the control group (1.00 - SD 0.10), except for patients with more than 3 years insulin treatment (1.11 SD 0.24) (Fig.3). We have subsequently analysed the Ig-fractions at a final 1:10 dilution after modifying the assay conditions as follows: Earle's-Hepes 1\% BSA medium was replaced by PBS $0.1 \%$ BSA, incubation at $15^{\circ} \mathrm{C}$ instead of at $4^{\circ} \mathrm{C}$ and no albumin supplement to the IgM and $\operatorname{IgG}$ column fractions. Sera from $17 / 30$ Type 1 diabetic patients at onset were still available and were re-tested under the modified conditions. No APSA-positive samples were detected in non-diabetic control subjects. In Type 1 diabetic patients at onset, the number of APSA-positive samples was two-fold higher when the Ig-fractions were assayed at 1:10 instead of 1:100 (Table 1). Samples which were APSApositive at 1:100 remained so at 1:10. The lower dilution resulted in a higher number of IgM-APSA and IgG-APSA positive serum fractions. Three of the five patients with IgG-APSA also contained IgM-APSA, whereas this was only the case for three of the $12 \mathrm{pa}$ tients without IgG-APSA. 


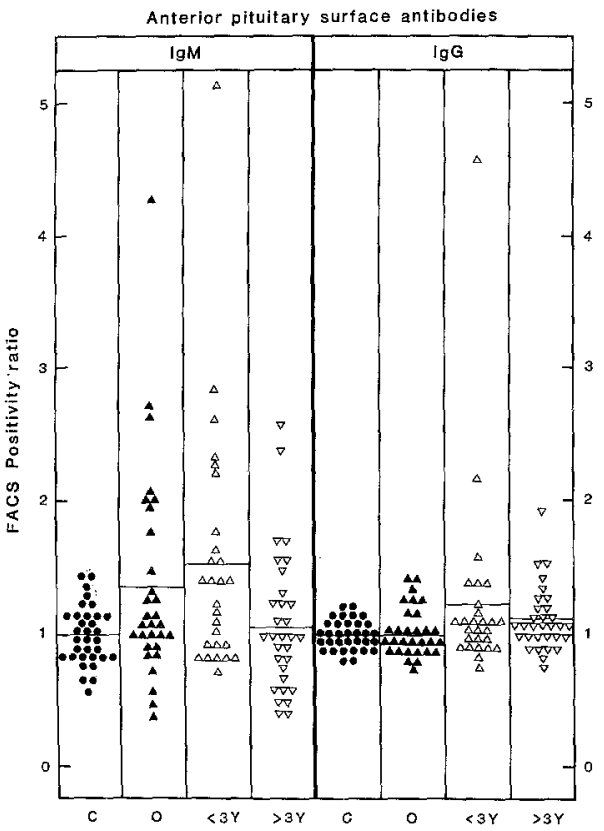

Fig.3. FACS positivity ratio's for rat pituitary cells incubated with IgM (left 4 columns) or $\operatorname{IgG}$ (right 4 columns) at 1:100 dilution. The immunoglobulin fractions have been prepared from healthy control subjects (c) and Type 1 (insulin-dependent) diabetic patients at onset (o), within 3 years $(<3 y)$ or after more than 3 years $(>3 y)$ of insulin treatment. Mean ratio's of patient groups are compared to the mean ratio of the control group and found to be significantly higher in patients at onset and within less than 3 years of insulin treatment for IgM-rat anterior pituitary cell surface antibodies (APSA) as well as in patients after more than 3 years of insulin treatment for IgG-APSA $(p<0.01)$

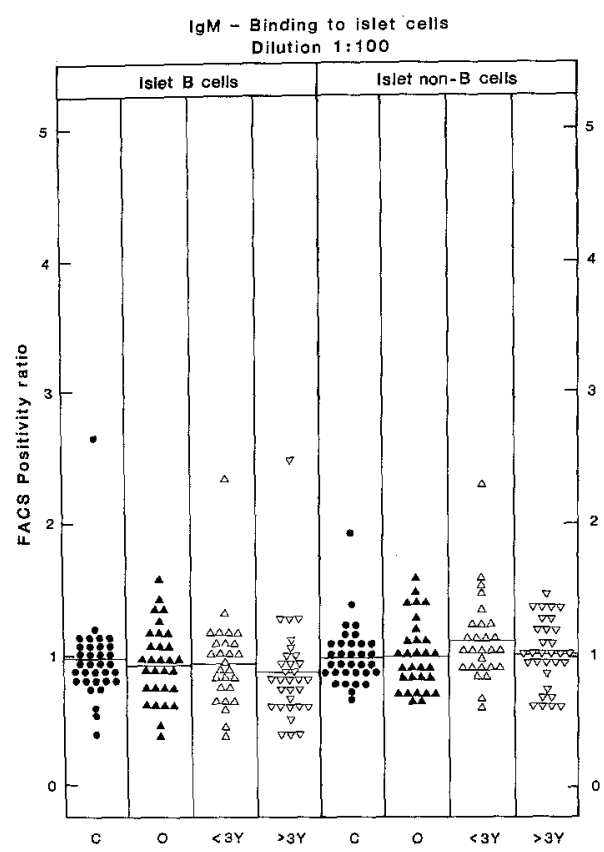

Fig.4. FACS positivity ratio's for rat islet cells incubated with IgM at 1:100 dilution. The immunoglobulin fractions have been prepared from healthy control subjects (c) and Type 1 (insulin-dependent) diabetic patients at onset $(0)$, within 3 years $(<3$ y) or after more than 3 years $(>3 y)$ of insulin treatment. Mean ratio's of patient groups are compared to the mean ratio of the control group and found not to be significantly higher
Table 1. Detection of cell surface antibodies in Type 1 (insulin-dependent) diabetic patients at onset

\begin{tabular}{llllll}
\hline Ig-class & Dilution & APSA & \multicolumn{2}{c}{ ICSA } & $\begin{array}{l}\text { APSA negative } \\
+\end{array}$ \\
\cline { 3 - 5 } & & & $\mathrm{B}$ & non-B & $\begin{array}{l}+ \text { ICSA negative } \\
\text { IgM }\end{array}$ \\
& $1: 100$ & $3 / 17$ & $0 / 17$ & $0 / 17$ & $14 / 17$ \\
& $1: 10$ & $6 / 17$ & $\mathrm{NT}$ & $2 / 17$ & $11 / 17$ \\
$\mathrm{IgG}$ & $1: 100$ & $2 / 17$ & $3 / 17$ & $1 / 17$ & $13 / 17$ \\
& $1: 10$ & $5 / 17$ & $5 / 17$ & $0 / 17$ & $11 / 17$ \\
$\mathrm{IgM}$ and/or & $1: 100$ & & & & \\
$\mathrm{IgG}$ & $1: 10$ & $8 / 17$ & $5 / 17$ & $2 / 17$ & $9 / 17$ \\
\hline
\end{tabular}

NT: Not tested APSA: Rat anterior pituitary cell surface antibodies; ICSA: Rat islet cell surface antibodies

\section{Characteristics of APSA}

That the membrane fluorescence obtained with IgM- or IgG-fractions was induced by these respective Igclasses was demonstrated by replacing the swine antihuman-Ig antibody by rat anti-human-IgM or rat antihuman-IgG antisera (1:10, Nordic). Binding was not eliminated by preincubating the immunoglobulins with $10^{-6} \mathrm{~mol} / 1$ porcine insulin. It was not correlated with the prevailing $\mathrm{HbA}_{1 \mathrm{c}}$ levels, nor was it inducible in APSA-negative Ig samples by in vitro glycosylation.

As the pituitary cell preparations were primarily composed of cells containing growth-hormone and prolactin, it was tested whether IgG- or IgM-APSA interacted specifically with one of these cell types. The cells with membrane fluorescence for APSA were sorted and examined immunocytochemically for growth-hormone and for prolactin. For the four IgM-APSA positive and three IgG-APSA positive samples tested, no preferential binding was observed with one particular cell type.

\section{Detection of islet cell surface antibodies (ICSA)}

When IgM-fractions were tested at a final 1:100 dilution on islet B cells, their mean FACS positivity ratio was $0.97 \pm 0.36$ (mean $\pm S D$ ) for the non-diabetic control subjects and $0.94 \pm 0.28$ for Type 1 diabetic patients at onset $(p>0.05)$ (Fig.4). At a final 1:10 dilution, some of the nondiabetic control subject samples produced an ICSA-positivity. Testing on islet non-B cells did not lead to any IgMpositivity at a $1: 100$ dilution; however, at a $1: 10$ dilution 2/17 IgM-fractions became positive (Table 1); both fractions also contained IgM-APSA.

The sera from some Type 1 diabetic patients contained $\operatorname{IgG}$ which bound to islet B cells (Fig. 5). At clinical onset, sera tested at a 1:10 dilution yielded a mean positivity ratio of $1.30 \pm 0.64$ (mean $\pm S D$ ) which was significantly $(p<0.01)$ higher than the ratio for nondiabetic control subjects (0.97 \pm 0.14$)$ (Fig.6). For patients with less than 3 years insulin treatment, the ratio $(1.58 \pm 0.43)$ was still significantly higher $(p<0.05)$ than for control subjects, and this was also the case after longer treatment $(1.15 \pm 0.40)$ (Fig.6). In contrast, no 


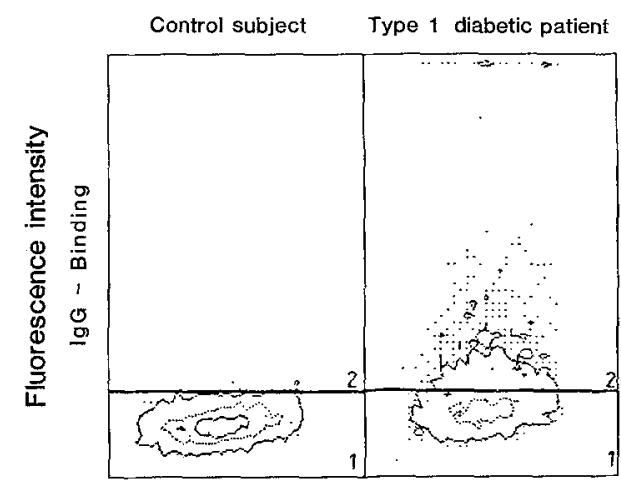

Forward scatter intensity

Fig.5. Facstar-analysis of IgG-binding to islet B cells purified from rat pancreas. Cells were incubated with IgG-fractions $(1: 10)$ and the cell-bound immunoglobulins labelled with rhodamine-conjugated anti-human immunoglobulins. Each cell is plotted according to forward scatter intensity and rhodamine-associated fluorescence intensity. The left panel represents a contourgraph for a rat islet B cell surface antibody (ICSA) negative sample from a non-diabetic control subject. More than $90 \%$ of the cells are recovered in the lower window. The right panel represents a contourgraph for an ICSA positive sample from a Type 1 (insulin-dependent) diabetic patient. More than $10 \%$ of the cells are recovered in the higher window

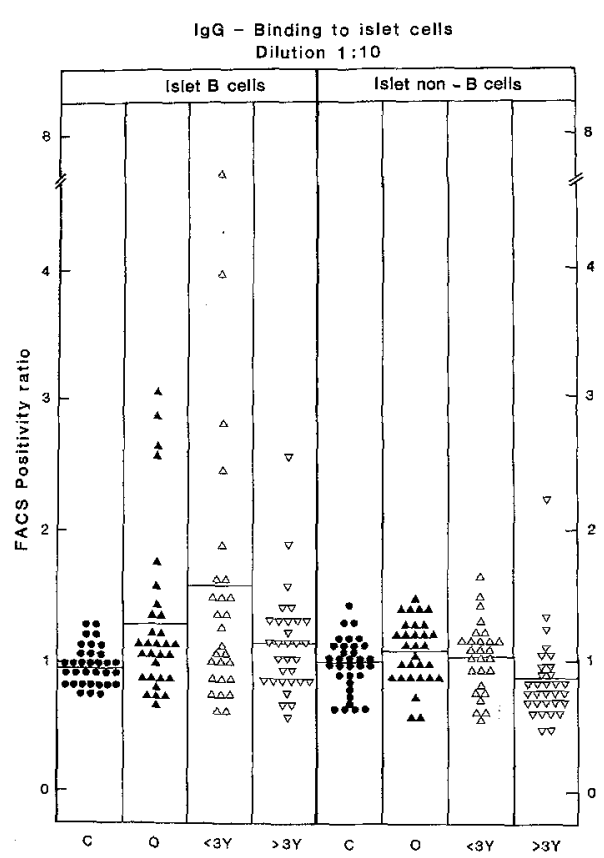

Fig.6. FACS positivity ratio for rat islet cells incubated with $\operatorname{IgG}$ at 1:10 dilution. The immunoglobulin fractions have been prepared from healthy control subjects (c) and Type 1 (insulin-dependent) diabetic patients at onset (o), within 3 years $(<3 \mathrm{y})$ or after more than 3 years $(>3 y)$ of insulin treatment. Mean ratio's of patient groups are compared to the mean ratio of the control group and found to be significantly higher for islet $B$ cell surface antibodies in patients at onset $(p<0.01)$ as well as within $(p<0.05)$ and after 3 years of insulin treatment $(p<0.01)$

surface binding was detected with islet non-B cells (Fig.6); this was confirmed by fluorescence microscopy. For 3 of 17 fractions, IgG-binding to islet B cells was still detectable at a final 1:100 dilution (Table 1). The IgG-binding to islet $\mathrm{B}$ cells was not altered by pre-
Table 2. Prevalence of surface antibodies in Type 1 (insulin-dependent) diabetic patients and first degree relatives ${ }^{\mathrm{a}}$

\begin{tabular}{|c|c|c|c|c|}
\hline \multirow[t]{2}{*}{ Ig-class } & \multirow{2}{*}{$\begin{array}{l}\text { Non-diabetic } \\
\text { control } \\
\text { subjects }\end{array}$} & \multicolumn{2}{|c|}{ Type 1 diabetic patients } & \multirow{2}{*}{$\begin{array}{l}\text { Non-diabetic } \\
1 \text { st degree } \\
\text { relatives }\end{array}$} \\
\hline & & At onset $>3$ & & \\
\hline & & & & \\
\hline IgG- $f$ & $0 / 3$ & $3 / 3$ & $7 / 3$ & 3 \\
\hline Ig-APSA & $0 / 33\left(0^{0}\right.$ & $9 / 30(30 \%)$ & $9 / 31(29 \%)$ & $9 / 18$ \\
\hline IgG-ICSA & $0 / 33(0 \%)$ & $7 / 30(23 \%)$ & $5 / 31(16 \%)$ & $1 / 18$ \\
\hline
\end{tabular}

a Assay at $1: 100$ dilution. $>3 \mathrm{y}$ : over 3 years of insulin treatment

incubating the immunoglobulins with $10^{-6} \mathrm{~mol} / 1$ porcine insulin and could not be attributed to glycosylation of immunoglobulins.

\section{Prevalence of APSA in Type 1 diabetic patients and their first degree relatives}

At a 1:100 dilution, the prevalence of APSA was $0 \%$ in the control group and 30\% in Type 1 diabetic patients (Table 2). At clinical onset of the disease, the IgMAPSA were more prevalent than the IgG-APSA, and occurred in almost all APSA-positive patients (8 of 9 Table 2). More than 3 years after diagnosis, APSA were still detectable but occurred now more frequently in the IgG-fraction (Table 2). At both stages, the occurrence of IgG-APSA was positively correlated to that of IgMAPSA $(p<0.02)$.

When the Ig-fractions were examined at a 1:10 dilution, the percentage of Type 1 diabetic patients with APSA at onset increased to almost 50\% (Table 1); the number of sera tested is, however, too small to compare the respective prevalence of IgM- and IgG-APSA. ICSA were not detected in the control group but were present in nearly $30 \%$ of the patients at clinical onset of the disease (Table 2). The detected ICSA represented IgG which bound to islet $B$ cells but not to other islet cells. A highly positive correlation $(p<0.001)$ was found between the occurrence of IgG-ICSA and that of IgG-APSA.

The presence of APSA was also examined in sera of non-diabetic first degree relatives of Type 1 diabetic patients. APSA were detected in 9 of 18 relatives and belonged primarily to the IgM-class (Table 2). This high prevalence of IgM-APSA contrasts with a low prevalence of IgG-ICSA (Table 2).

\section{Adsorption of IgM-APSA to pituitary and non-pituitary cells}

APSA-positive IgM-fractions were preincubated at a 1:100 dilution with intact pituitary and non-pituitary cells to examine whether the APSA were selectively removed by any of the tested cell types. At the end of incubation, the presence of APSA in the supernatant was assessed on freshly prepared pituitary cells. For each of 
the 9 tested samples, preincubation with pituitary cells resulted in a reduction of the positivity ratio, and for 4 of 9, IgM-APSA were completely removed. After preincubation with islet cells, the positivity ratio was reduced for 3 of 9 samples but complete removal was only noticed in 1 of 9 . On the contrary, preincubation with splenocytes reduced the APSA-positivity in all samples and removed it completely for 6 of 9 .

APSA and ICSA-positive IgG fractions were also preincubated with intact pituitary cells (at a 1:10 dilution), and then retested for binding to freshly prepared pituitary and islet B cells. Both the pituitary cell and islet $B$ cell surface antibodies were absorbed by this treatment as shown by a threefold decrease in the respective positivity ratio's.

\section{Discussion}

The presence of islet cell antibodies in sera of Type 1 diabetic patients has often been reported [1-7]. Cell binding immunoglobulins are usually detected by immunofluorescence microscopy on normal or tumoural cells or tissue. Most techniques are based on poorly standardized and relatively subjective parameters. Visual judgement of the fluorescent reaction can vary with occular adaptation and photobleaching of the illuminated fluorochrome. The fluorescent signal is not quantified and non-specific background is sometimes difficult to discern from poorly positive samples. One way to circumvent several of these limitations consists in measuring immunoglobulin binding by a protein-A sepharose assay $[23,24]$. We describe another method wherein immunoglobulin binding to single and viable B cells is quantified by FACS analysis. With this procedure the number of cells are counted which exhibit a fluorescence intensity above a control value. The method was also employed for measuring surface binding to islet non B cells and to pituitary cells. Possible limitations are the use of animal cells for detecting human antibodies and the restriction to surface binding immunoglobulins.

Assay conditions were selected so that virtually no binding occurred with immunoglobulins from nondiabetic control subjects. This may require different dilutions for IgM and IgG. Possible interactions between both Ig-classes were also to be eliminated. We therefore fractionated each serum into $\operatorname{IgM}$ - and $\operatorname{IgG}$ samples before determining their final dilutions at, respectively, $1: 100$ and $1: 10$. These experimental conditions may underestimate the number of diabetic patients with surface antibodies, as they also minimize detection of positive samples in the non-diabetic control group. The method is rather focused on assessing differences in the appearance of cell surface antibodies between diabetic and non-diabetic control subjects. It can not exclude that negatively scored samples also contain surface antibodies but at a lower concentration and/or binding affinity than those in positive sera. The possibility thus exists that antibodies detected by the present technique correspond to natural autoantibodies [25] which are produced at a higher rate and/or affinity.

As described previously [7] several Type 1 diabetic patients under 20 produce $\mathrm{IgG}$ which bind to the surface of rat islet B cells. It was confirmed that no IgG binding occurred with other islet cells [7]. On the other hand, IgG binding did occur with other rat endocrine cells, namely those of the anterior pituitary. This binding was not prevented by the addition of insulin or by varying the albumin concentrations, and appeared not to be caused by protein glycosylation. It occurred with both the growth hormone containing and prolactin containing cells, which constituted more than $85 \%$ of the total cell preparation. That only 10 to $40 \%$ of the cells were fluorescently labelled in the APSA-assay may result from functional differences between homologous cells but could also be the consequence of variable surface damage during the dissociation procedure. The latter possibility was not supported by studies on overnight-cultured cells as these yielded essentially the same binding pattern; their higher degree of cell aggregation made them less suitable for FACS analysis.

At clinical onset of the disease, the prevalence of APSA was comparable to that of ICSA, with a positive correlation being observed in their respective occurrence. Pituitary cell surface binding occurred with both IgM and IgG-fractions whereas islet cell binding was only detected with IgG. Intact pituitary cells adsorbed IgM- and IgG-APSA as well as IgG-ICSA. Tissue adsorption is, however, relatively inaccurate in testing cross-reactivity of surface antibodies as it may, at low antibody dilutions, also lead to their aspecific adsorption. This could, for example, explain the partial adsorption of some IgM-APSA by intact islet B cells. With splenocytes, on the other hand, the IgM-APSA were almost completely adsorbed, which raises the possibility of their cross-reactivity with lymphocyte surface antigens. Further characterization of the surface antibodies in recent onset Type 1 diabetic subjects will thus require testing of their binding to other cell types, including cells from human origin and identification of the respective antigens. In the light of recent studies in normal subjects [25], it seems particularly interesting to examine whether the presently detected IgM-surface antibodies correspond to natural polyreactive autoantibodies which are produced at a higher rate or higher affinity in recent-onset Type 1 diabetic subjects.

The prevalence of IgM-APSA was higher at onset than after 3 years of insulin treatment whereas the reverse was noticed for IgG-APSA. The IgM-APSA were also detected in first-degree relatives of Type 1 diabetic patients where their prevalence was higher than that of IgG-APSA or that of IgG-ICSA. These results suggest that the development of Type 1 diabetes in subjects younger than 20 years is associated with the (increased) formation of IgM surface antibodies in sev- 
eral patients and first-degree relatives under age 20 . The stimuli leading to this IgM-production are still unknown. They could be of genetic or of environmental origin, and may, as such, express predisposition to Type 1 diabetes but also to other diseases with increased autoantibody formation. The assay of IgM surface antibodies can be useful in detecting those episodes of immune stimulation and in identifying the conditions which switch the production of polyreactive $\operatorname{IgM}$ into the generation of monoreactive and high affinity IgG-autoantibodies which may mark the progression of a particular disease.

Acknowledgements. We thank Mr. G.Stangé and Ms. A.Demarré for excellent technical assistance, Ms. N. Van Slycke and Ms. A. De Nil for reliable secretarial support, Dr. E. Hooghe-Peeters and Dr. B. Velkeniers for help in preparing and characterizing the pituitary cells. We are indebted to Dr. L. Kaufman for statistical advice and Drs. H. Loeb and N.Balduck (Pediatric Department of the A.Z.-VUB Brussel), Dr. I. De Leeuw (Universitair Ziekenhuis Antwerpen), Dr. M. Coeckelberghs (Good-Engels Ziekenhuis Antwerpen) Dr. G. Lamberigts (Algemeen Ziekenhuis St.Jan, Brugge) and Dr. R. Rottiers (Universitair Ziekenhuis Gent) for sending us sera from diabetic patients. This work is supported by grants 3.0088 .86 and 3.0033 .87 from the Belgian Fonds voor Geneeskundig Wetenschappelijk Onderzoek, and grant 86/91-102 from the Belgian Ministerie voor Wetenschapsbeleid.

\section{References}

1. Bottazzo GF, Florin-Christensen A, Doniach D (1974) Islet-cell antibodies in diabetes mellitus with autoimmune polyendocrine deficiences. Lancet II: 1279-1282

2. MacCuish AC, Irvine WJ, Barnes EW, Duncan LJP (1974) Antibodies to pancreatic islet cells in insulin-dependent diabetics with coexistent autoimmune disease. Lancet II: 1529-1531

3. Lendrum R, Walker G, Cudworth AG, Theophanides C, Pyke DA, Bloom A, Gamble DR (1976) Islet-cell antibodies in diabetes mellitus. Lancet II: 1273-1276

4. MacLaren NK, Huang S-W, Fogh J (1975) Antibody to cultured human insulinoma cells in insulin-dependent diabetes. Lancet I: $997-1000$

5. Lernmark Å, Freedman ZR, Hofmann C, Rubenstein AH, Steiner DF, Jackson RL, Winter RJ, Traisman HS (1978) Isletcell-surface antibodies in juvenile diabetes mellitus. N Engl J Med 299: 375-380

6. Baekkeskov S, Nielsen JH, Marner B, Bilde T, Ludvigsson J, Lernmark $\AA$ (1982) Autoantibodies in newly diagnosed diabetic children immunoprecipitate human pancreatic islet cell proteins. Nature 298: 167-169

7. Van De Winkel M, Smets G, Gepts W, Pipeleers D (1982) Islet cell surface antibodies from insulin-dependent diabetics bind specifically to pancreatic B cells. J Clin Invest 70: 41-49

8. Gorsuch AN, Spencer KM, Lister J, McNally JM, Dean BM, Bottazzo GF, Cudworth AG (1981) Evidence for a long prediabetic period in type I (insulin-dependent) diabetes mellitus. Lancet II: 1363-1365

9. Srikanta S, Ganda OP, Rabizadeh A, Soeldner JS, Eisenbarth GS (1985) First-degree relatives of patients with type I diabetes mellitus. Islet-cell antibodies and abnormal insulin secretion. N Engl J Med 313: 461-464

10. Baekkeskov $S$, Landin $M$, Kristensen JK, Srikanta $S$, Bruining GJ, Mandrup-Poulsen T, de Beaufort C, Soeldner JS, Eisen- barth G, Lindgren F, Sundquist G, Lernmark $\AA$ (1987) Antibodies to a $64,000 \mathrm{M}_{\mathrm{r}}$ human islet cell antigen precede the clinical onset of insulin-dependent diabetes. J Clin Invest 79:926-934

11. Irvine WJ, McCallum CJ, Gray RS, Campbell CJ, Duncan LJP, Farquhar JW, Vaughan H, Morris PJ (1977) Pancreatic islet-cell antibodies in diabetes mellitus correlated with the duration and type of diabetes, coexistent autoimmune disease, and HLA type. Diabetes 26: 138-147

12. Lernmark $\AA$, Hägglöf $B$, Freedman $Z$, Irvine $J$, Ludvigsson J, Holmgren G (1981) A prospective analysis of antibodies reacting with pancreatic islet cells in insulin-dependent diabetic children. Diabetologia 20: 471-474

13. Mirakian R, Cudworth AG, Bottazzo GF, Richardson CA, Doniach D (1982) Autoimmunity to anterior pituitary cells and the pathogenesis of insulin-dependent diabetes mellitus. Lancet I: 755-759

14. Schopfer K, Matter L, Tenschert R, Bauer S, Zuppinger K (1984) Anti-glucagon-cell and anti-adrenal-medullary-cell antibodies in islet-cell-autoantibody-positive diabetic children. N Engl J Med 310: $1536-1537$

15. Brown FM, Kamalesh M, Sesh Adri MN, Rabinowe SL (1988) Anti-adrenal medullary antibodies in IDDM subjects and subjects at high risk of developing IDDM. Diabetes Care 11: 30-33

16. Pipeleers DG, Pipeleers-Marichal MA (1981) A method for the purification of single $A, B$ and D cells and for the isolation of coupled cells from isolated rat islets. Diabetologia 20:654-663

17. Van De Winkel M, Maes E, Pipeleers D (1982) Islet cell analysis and purification by light scatter and autofluorescence. Biochem Biophys Res Commun 107: 525-532

18. Pipeleers DG, in't Veld PA, Van De Winkel M, Maes E, Schuit FC, Gepts W (1985) A new in vitro model for the study of pancreatic A and B cells. Endocrinology 117: 806-816

19. Denef C, Hautekeete E, De Wolf A, Vanderschueren B (1978) Pituitary basophils from immature male and female rats: distribution of gonadotrophs and thyrotrophs as studied by unit gravity sedimentation. Endocrinology 103: 724-735

20. Velkeniers B, Smets G, Baldys A, Buydens P, Finné E, Vanhaelst $\mathrm{L}$ (1987) Linear percoll gradient centrifugation of rat anterior pituitary cells. A simple method for prolactin cell enrichment. $\mathrm{J}$ Endocrinol Invest 10: 247-253

21. Simon M, Cuan J (1982) Hemoglobin $A_{1 c}$ by isoelectric focusing. Clin Chem 28:9-12

22. Baker JR, Metcalf PA, Johnson RN, Newman D, Rietz P (1985) Use of protein-based standards in automated colorimetric determinations of fructosamine in serum. Clin Chem 31: 1550-1554

23. Dyrberg T, Nakhooda AF, Baekkeskov S, Lernmark $\AA$, Poussier P, Marliss EB (1982) Islet cell surface antibodies and lymphocyte antibodies in the spontaneously diabetic BB Wistar rat. Diabetes 31: 278-281

24. Huen AH-J, Haneda M, Freedman Z, Lernmark $\AA$, Rubenstein AH (1983) Quantitative determination of islet cell surface antibodies using ${ }^{125}$ I-protein A. Diabetes 32: 460-465

25. Guilbert B, Dighiero G, Avrameas S (1982) Naturally occurring antibodies against nine common antigens in normal humansera I. Detection, isolation and characterization. J Immunol 128: 2779-2787

Received: 25 November 1988

and in revised form: 22 May 1989

\section{Dr. D.Pipeleers}

Department of Metabolism and Endocrinology

Vrije Universiteit

Laarbeeklaan 103

B-1090 Brussels

Belgium 